\title{
Proteomics analysis of high lipid-producing strain Mucor circinelloides WJ11: an explanation for the mechanism of lipid accumulation at the proteomic level
}

\author{
Xin Tang ${ }^{1}$, Xinyi Zan ${ }^{1}$, Lina Zhao ${ }^{1}$, Haiqin Chen ${ }^{1,3}$, Yong Q. Chen ${ }^{1,3}$, Wei Chen ${ }^{1,3}$, Yuanda Song ${ }^{1,2^{*}}$ \\ and Colin Ratledge ${ }^{4}$
}

\begin{abstract}
Background: The oleaginous fungus, Mucor circinelloides, is attracting considerable interest as it produces oil rich in $Y$-linolenic acid. Nitrogen ( $\mathrm{N}$ ) deficiency is a common strategy to trigger the lipid accumulation in oleaginous microorganisms. Although a simple pathway from $\mathrm{N}$ depletion in the medium to lipid accumulation has been elucidated at the enzymatic level, global changes at protein levels upon $\mathrm{N}$ depletion have not been investigated. In this study, we have systematically analyzed the changes at the levels of protein expression in M. circinelloides WJ11, a high lipidproducing strain (36\%, lipid/cell dry weight), during lipid accumulation.
\end{abstract}

Results: Proteomic analysis demonstrated that $\mathrm{N}$ depletion increased the expression of glutamine synthetase, involved in ammonia assimilation, for the supply of cellular nitrogen but decreased the metabolism of amino acids. Upon N deficiency, many proteins (e.g., fructose-bisphosphate aldolase, glyceraldehyde-3-phosphate dehydrogenase, enolase, pyruvate kinase) involved in glycolytic pathway were up-regulated while proteins involved in the tricarboxylic acid cycle (e.g., isocitrate dehydrogenase, succinyl-CoA ligase, succinate dehydrogenase, fumarate hydratase) were down-regulated, indicating this activity was retarded thereby leading to a greater flux of carbon into fatty acid biosynthesis. Moreover, glucose-6-phosphate dehydrogenase, transaldolase and transketolase, which participate in the pentose phosphate pathway, were up-regulated, leading to the increased production of NADPH, the reducing power for fatty acid biosynthesis. Furthermore, protein and nucleic acid metabolism were down-regulated and some proteins involved in energy metabolism, signal transduction, molecular chaperone and redox homeostasis were upregulated upon $\mathrm{N}$ depletion, which may be the cellular response to the stress produced by the onset of $\mathrm{N}$ deficiency.

Conclusion: $\mathrm{N}$ limitation increased those expressions of the proteins involved in ammonia assimilation but decreased that involved in the biosynthesis of amino acids. Upon $\mathrm{N}$ deprivation, the glycolytic pathway was upregulated, while the activity of the tricarboxylic acid cycle was retarded, thus, leading more carbon flux to fatty acid biosynthesis. Moreover, the pentose phosphate pathway was up-regulated, then this would increase the production of NADPH. Together, coordinated regulation of central carbon metabolism upon $\mathrm{N}$ limitation, provides more carbon flux to acetyl-CoA and NADPH for fatty acid biosynthesis.

Keywords: Lipid accumulation, Mucor circinelloides, Nitrogen deficiency, Proteomics

\footnotetext{
*Correspondence: ysong@jiangnan.edu.cn

1 State Key Laboratory of Food Science and Technology, School of Food

Science and Technology, Jiangnan University, Wuxi, People's Republic

of China

Full list of author information is available at the end of the article
} 


\section{Background}

Oleaginous microorganisms include fungi, yeasts, microalgae and bacteria that can accumulate oil to more than $20 \%$ of their cell dry weight (CDW) [1]. The metabolism of lipid accumulation in oleaginous microorganisms has been extensively studied as microbial oils can be used as commercial sources of several nutritionally-important polyunsaturated fatty acids (PUFAs) and as potential sources of biofuels [2, 3]. Among oleaginous filamentous fungi, Mucor circinelloides has been considered as an important model organism for lipid accumulation studies due to its ability to produce an oil rich in $\gamma$-linolenic acid (GLA, 18:3; n-6), that may have beneficial effects for the treatment of premenstrual tension, atopic dermatitis and some other diseases [4] and also due to the availability of genome data and genetic tools.

Lipid accumulation in oleaginous microorganisms is triggered by a nutrient imbalance in the culture medium. When cells run out of a key nutrient, usually nitrogen $(\mathrm{N})$, excess carbon substrate continues to be assimilated by the cells and converted into storage lipids [3]. The biochemistry of lipid accumulation in oleaginous microorganisms triggered by $\mathrm{N}$ deficiency has been widely investigated. Previous data indicated that the activity of isocitrate dehydrogenase decreases rapidly and even ceases completely under $\mathrm{N}$-deficient conditions as the diminishing concentration of its allosteric regulator AMP, and then results in a shift in carbon flux through the citric acid cycle and into lipid biosynthesis $[5,6]$. In addition, ATP: citrate lyase (ACL), which generates acetyl-CoA as the precursor of fatty acids via the cleavage of citric acid, is an essential enzyme for fatty acid biosynthesis and possibly catalyzes the rate-limiting reaction for fatty acid biosynthesis in some oleaginous organism [7-9].

Beside acetyl-CoA, the provision of reducing power in the form of NADPH is another critical process for fatty acid biosynthesis. The key roles of malic enzyme and the pentose phosphate pathway (glucose-6-phosphate dehydrogenase coupled with 6-phosphogluconate dehydrogenase) to supply NADPH for fatty acid synthesis during lipid accumulation have been proposed [2, 1017]. However, lipid accumulation is a complicated process involving many metabolic pathways and thus it is impossible to achieve maximal lipid production simply by regulating just one or two genes. An investigation of lipid metabolism at systematic level is therefore required to gain insights into the molecular mechanism of lipid accumulation.

Cellular responses to $\mathrm{N}$ deficiency are the subtle behaviors of living organisms. Although there are alternative approaches to understand the molecular mechanisms of cellular response under $\mathrm{N}$ deficiency, microbial proteomics has become a powerful tool to investigate the complex cellular processes. In addition, it can also determine new functions of gene products as it represents not only the gene product, but also translational rate and post-translational modifications. Identification of proteins that are up/down-regulated under $\mathrm{N}$ deficiency is important in studying the mechanisms of lipid accumulation. Accordingly, comparative proteomics have been explored to gain insights into the lipid metabolism under $\mathrm{N}$ deficiency in microalgae and yeast [18-21].

M. circinelloides was the first microorganism to be used commercially to produce an oil for human consumption-an oil rich in GLA [4]. However, the process began in 1985 but lasted only 6 years as the commercial strain only produced $25 \%$ lipid of its cell biomass and at that time high GLA-producing plant species came on to the market $[3,4]$. In this study, we performed a comparative proteomic study on the oleaginous fungus $M$. circinelloides WJ11, which is the highest lipid-producing strain (up to $36 \%$ lipid, w/w) of this species as far and its lipid content is much higher than that commercial strain [6]. M. circinelloides WJ11 could be the potential strain to produce the commercial oil rich in GLA and its mechanism of lipid accumulation at proteomic level will provide a foundation of restarting the commercial production of GLA by microorganism. We compared proteomes from three growth stages (the balanced growth stage, the fast lipid accumulation stage and the slow lipid accumulation stage) to provide new insights into the mechanism of lipid metabolism in this fungus. To the best of our knowledge, this is the first proteomic study on the lipid overproduction process of the oleaginous filamentous fungus, M. circinelloides WJ11, under N deficiency.

\section{Results and discussion}

Cell growth and lipid accumulation in M. circinelloides WJ11 In most oleaginous microorganisms, the amount of lipid increases under $\mathrm{N}$ starvation and lipid accumulation is often investigated by comparing the $\mathrm{N}$ rich phase to $\mathrm{N}$ deficiency phase in the entire bioprocess $[10,18,22]$. The concentrations of ammonium and glucose in culture medium, cell dry weight (CDW), and lipid accumulation of $M$. circinelloides WJ11 during growth are shown in Fig. 1. Ammonium was used up at approx. $9 \mathrm{~h}$ and glucose remained in excess during the entire bioprocess. CDW initially increased rapidly up to $9 \mathrm{~h}$ of growth, and then slowed down after nitrogen exhaustion. Immediately after nitrogen depletion from the growth medium, the fungus started to accumulate lipids; from 9 to $48 \mathrm{~h}$, the total fatty acids (TFAs) content increased rapidly and then slowed. The maximal TFAs content in M. circinelloides WJ11 was $36 \%$ CDW; this was considerably greater than that in other strains of the fungus: CBS 


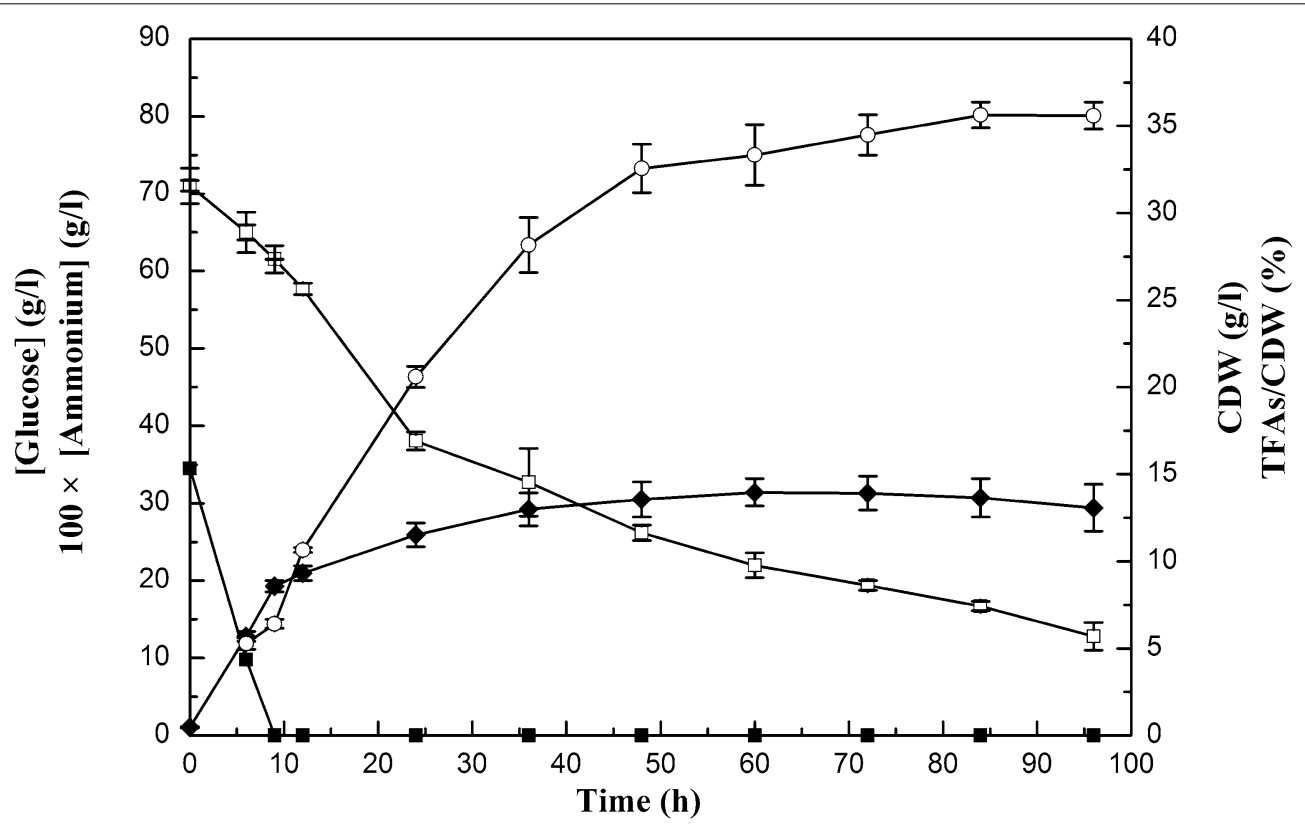

Fig. 1 Cell growth and lipid accumulation of M. circinelloides WJ11. Ammonium and glucose concentration in the growth media, cell dry weight (CDW) and total fatty acids (TFAs) content (W/W, CDW) of strain WJ1 1 in the modified K \& R medium in 2 L fermenter. Open square glucose concentration; filled square ammonium concentration, filled diamond CDW, open circle TFAs/CDW. Values were measured as mean of three biological replicates. Error bars represent the standard error of the mean

$277.49(10-15 \%, w / w)$ and CBS $108.16(20-25 \%, w / w)$ $[10,23,24]$. In this study, the cells of $M$. circinelloides WJ11 were collected at $6 \mathrm{~h}$ ( $\mathrm{N}$ rich and balanced growth stage), $24 \mathrm{~h}$ (after $\mathrm{N}$ depletion and fast lipid accumulation stage) and $60 \mathrm{~h}$ (after $\mathrm{N}$ depletion and slow lipid accumulation stage) for further research.

Furthermore, we also calculated the average rate of lipid biosynthesis in $M$. circinelloides WJ11 during the bioprocess (Table 1 ). The result showed the rate of lipid production goes up after $\mathrm{N}$ exhaustion at $9 \mathrm{~h}$ (the

Table 1 Average lipid biosynthesis rate in M. circinellodies WJ11 during the bioprocess

\begin{tabular}{|c|c|}
\hline Time & $\begin{array}{l}\text { Average lipid biosynthesis } \\
\text { rate }^{\mathrm{a}}\left(\mathrm{mg} \mathrm{g}^{-1} \mathrm{~h}^{-1}\right)\end{array}$ \\
\hline From 6 to $9 \mathrm{~h}$ & 12.4 \\
\hline From 9 to $12 \mathrm{~h}$ & 18 \\
\hline From 12 to $24 \mathrm{~h}$ & 13.1 \\
\hline From 24 to $36 \mathrm{~h}$ & 11.5 \\
\hline From 36 to $48 \mathrm{~h}$ & 6.8 \\
\hline From 48 to $60 \mathrm{~h}$ & 2.2 \\
\hline From 60 to $72 \mathrm{~h}$ & 1.3 \\
\hline From 72 to $84 \mathrm{~h}$ & 0.6 \\
\hline From 84 to $96 \mathrm{~h}$ & 0 \\
\hline
\end{tabular}

a Average lipid biosynthesis rate was calculated by the synthesized lipid per gram lipid-free cell dry weight per hour rate from 12 to $24 \mathrm{~h}$ is higher than from 6 to $9 \mathrm{~h}$ ), and decreases after $36 \mathrm{~h}$.

\section{Proteome analysis of $M$. circinelloides during lipid accumulation upon $\mathrm{N}$ deficiency}

To investigate the differentially expressed proteins of M. circinelloides WJ11 during lipid accumulation triggered by $\mathrm{N}$ depletion, proteomic analysis was applied by 2-DE at 6, 24 and $60 \mathrm{~h}$, which, respectively, represent three growth stages: balanced growth stage ( $3 \mathrm{~h}$ before $\mathrm{N}$ depletion); the fast lipid accumulation phase (15 h after $\mathrm{N}$ depletion); and the slow lipid accumulation phase (51 $\mathrm{h}$ after $\mathrm{N}$ depletion). The representative gels of protein spots from the different stages are shown in Fig. 2. More than 800 spots were detected in each gel and 118 of these spots showed significant changes ( $>1.5$-fold or $<0.67$-fold) under $\mathrm{N}$ deficiency. The differential protein spots were excised from the gels for MALDI-TOF/TOF MS analyses and these identified proteins were shown in Table 2 .

\section{Nitrogen and amino acid metabolism}

Glutamine synthase (GS) is the key enzyme involved in ammonia assimilation in both plants and microorganisms $[25,26]$. Previous proteomic analysis has indicated that its expression is induced immediately following $\mathrm{N}$ deprivation in both Phaeodactylum tricornutum and 


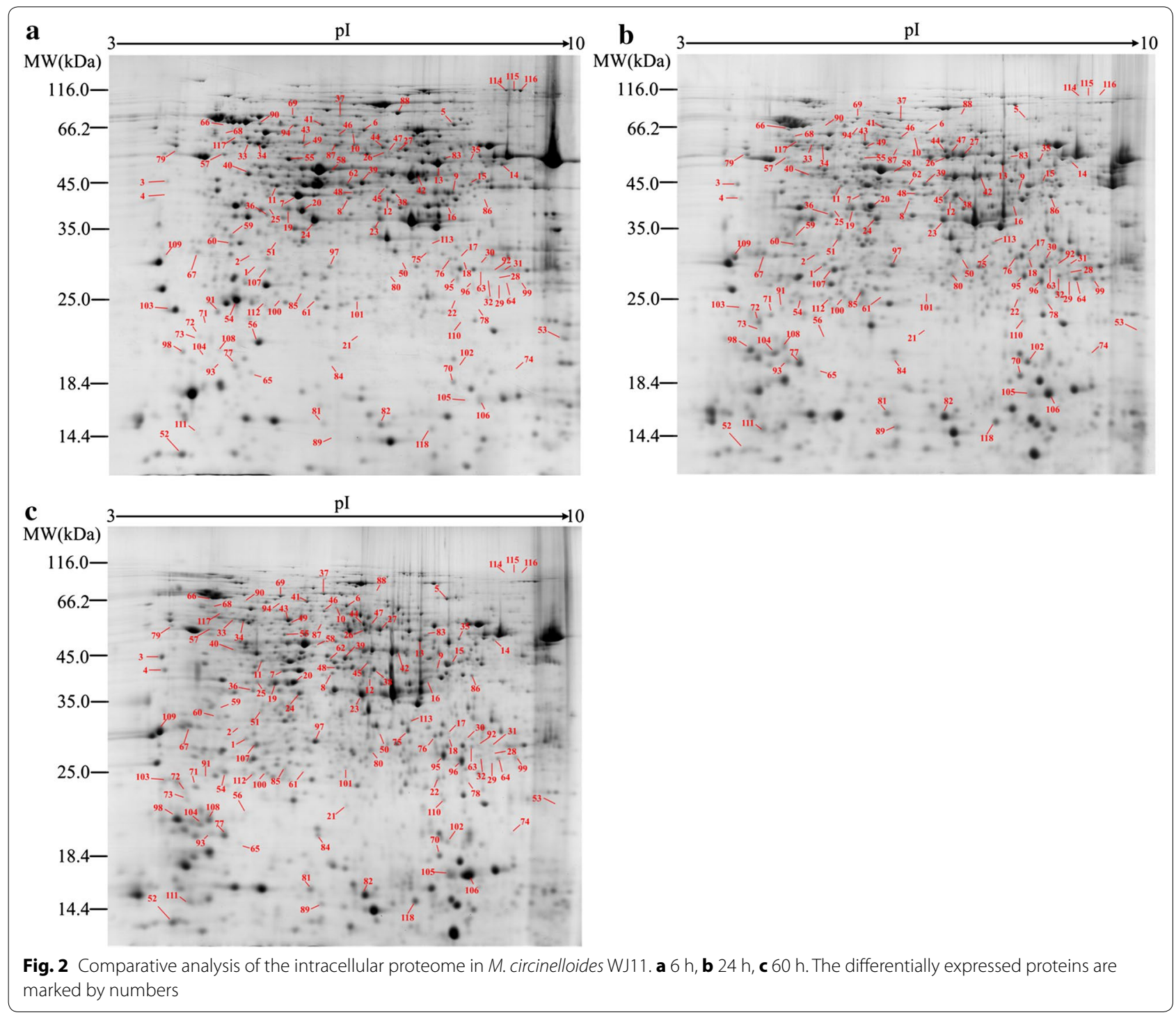

Rhodosporidium toruloides [18, 21]. Indeed, our result showed its expression (spots 1 and 2) in M. circinelloides was up-regulated upon $\mathrm{N}$ depletion. In oleaginous yeasts, upon $\mathrm{N}$ deficiency and at the beginning of lipid accumulation, AMP is deaminated to release ammonium for further cell use. Thus, the substrate $\mathrm{NH}_{4}{ }^{+}$for GS might be from the degradation of AMP or other $\mathrm{N}$ compounds. Saccharopepsin (spots 3 and 4), which links to vacuolar protein degradation, was also induced upon $\mathrm{N}$ depletion in this study. The elevated expression of this protein would enhance degradation of proteins suggesting that, immediately after $\mathrm{N}$ exhaustion, the cells initiate the turnover and recycling of intracellular componentsespecially proteins that are no longer needed for anabolic reactions [12].
Most of the proteins associated with amino acid metabolism showed decreased expression level after $\mathrm{N}$ depletion. Acetolactate synthase (spot 5), dihydroxyacid dehydratase (spot 6) and ketol-acid reductoisomerase (spot 7) catalyze the synthesis of the branched-chain amino acids (BCAA, e.g., valine, leucine, and isoleucine) [27-29], and branched-chain amino acid aminotransferase (spot 8) participates in the degradation BCAA [30]. These proteins related to $\mathrm{BCAA}$ metabolism were all down-regulated upon $\mathrm{N}$ depletion. Acetylornithine aminotransferase (spot 9) and asparagine synthetase (spot 10) are involved in the asparagine biosynthesis [31]. Saccharopine dehydrogenase (spot 11) and homoisocitrate dehydrogenase (spot 12) participate in lysine biosynthesis [32, 33]. Serine hydroxymethyltransferase (spots 13 and 
Table 2 Identification of differentially expressed proteins under N deficiency in M. circinellodies WJ11 by MALDI-TOF/TOF analysis

\begin{tabular}{|c|c|c|c|c|c|c|c|c|}
\hline Spot & Accession & Protein name & $\begin{array}{l}\text { Theoretical } \\
\mathrm{MW}(\mathrm{Da}) / \mathrm{pl}\end{array}$ & $\begin{array}{l}\text { MASCOT } \\
\text { score }\end{array}$ & $\begin{array}{l}\text { No. } \\
\text { matched }\end{array}$ & $\begin{array}{l}\text { Coverage } \\
\text { (\%) }\end{array}$ & $\begin{array}{l}\text { Fold } \\
\text { change } \\
24 \mathrm{~h} / 6 \mathrm{~h}\end{array}$ & $\begin{array}{l}\text { Fold } \\
\text { change } \\
60 \mathrm{~h} / 6 \mathrm{~h}\end{array}$ \\
\hline \multicolumn{9}{|c|}{ Nitrogen metabolism } \\
\hline 1 & gi|511001426 & Glutamine synthetase & $39,973 / 5.61$ & 73 & $2(0)$ & 6 & 14.49 & 5.58 \\
\hline 2 & gi|511003862 & Glutamine synthetase & $40,412 / 5.61$ & 102 & $2(2)$ & 11 & 15.04 & 2.79 \\
\hline 3 & gi|511008284 & Saccharopepsin & $44,921 / 4.81$ & 243 & $5(2)$ & 17 & 37.86 & 60.50 \\
\hline 4 & gi|511001898 & Saccharopepsin & $44,736 / 4.91$ & 129 & $3(0)$ & 8 & 36.84 & 91.88 \\
\hline \multicolumn{9}{|c|}{ Amino acid metabolism } \\
\hline 5 & gi|511002358 & Acetolactate synthase & $73,772 / 8.13$ & 297 & $5(1)$ & 10 & 0.02 & 1.03 \\
\hline 6 & gi|511004294 & Dihydroxy-acid dehydratase & $64,148 / 6.27$ & 432 & $8(4)$ & 11 & 0.55 & 0.82 \\
\hline 7 & gi|511002359 & Ketol-acid reductoisomerase & $44,298 / 7.72$ & 562 & $9(3)$ & 27 & 0.10 & 0.17 \\
\hline 8 & gi|511004962 & $\begin{array}{l}\text { Branched-chain amino acid } \\
\text { aminotransferase }\end{array}$ & $43,753 / 6.62$ & 474 & $6(3)$ & 19 & 0.38 & 0.59 \\
\hline 9 & gi|511010054 & $\begin{array}{l}\text { Acetylornithine aminotrans- } \\
\text { ferase }\end{array}$ & $49,342 / 8.32$ & 123 & $4(1)$ & 15 & 0.75 & 0.37 \\
\hline 10 & gi|511006376 & Asparagine synthetase & $64,754 / 5.81$ & 88 & $3(0)$ & 8 & 0.15 & 0.80 \\
\hline 11 & gi|511005296 & Saccharopine dehydrogenase & $41,899 / 5.36$ & 471 & $12(3)$ & 35 & 0.38 & 0.29 \\
\hline 12 & gi|511002126 & Homoisocitrate dehydrogenase & $41,047 / 6.28$ & 102 & $3(0)$ & 10 & 0.29 & 0.15 \\
\hline 13 & gi|511009910 & $\begin{array}{l}\text { Serine hydroxymethyltrans- } \\
\text { ferase } 2\end{array}$ & $51,589 / 6.53$ & 193 & $8(2)$ & 24 & 0.39 & 0.31 \\
\hline 14 & gi|511001743 & $\begin{array}{l}\text { Serine hydroxymethyltransferase, } \\
\text { mitochondrial }\end{array}$ & $55,707 / 8.97$ & 109 & $4(1)$ & 11 & 0.30 & 0.22 \\
\hline 15 & gi|511000252 & $\begin{array}{l}\text { Glycine cleavage system } T \\
\text { protein }\end{array}$ & $43,694 / 8.77$ & 82 & $4(0)$ & 11 & 0.18 & 0.47 \\
\hline 16 & gi|511004260 & $\begin{array}{l}\text { 3-Deoxy-7-phosphoheptulonate } \\
\text { synthase }\end{array}$ & $38,738 / 6.46$ & 239 & $4(1)$ & 9 & 0.20 & 0.10 \\
\hline 17 & gi|511010625 & S-Adenosylmethionine synthase & $42,413 / 5.67$ & 70 & $1(1)$ & 3 & 5.39 & 3.55 \\
\hline 18 & gi|511010625 & S-Adenosylmethionine synthase & $42,413 / 5.67$ & 106 & $1(1)$ & 3 & 3.22 & 1.41 \\
\hline \multicolumn{9}{|c|}{ Carbon metabolism } \\
\hline 19 & gi|511002640 & Fructose-bisphosphate aldolase & $39,791 / 5.36$ & 145 & $2(2)$ & 11 & 1.64 & 2.99 \\
\hline 20 & gi|511002640 & Fructose-bisphosphate aldolase & $39,791 / 5.36$ & 236 & $3(1)$ & 11 & 1.55 & 1.51 \\
\hline 21 & gi|511008895 & $\begin{array}{l}\text { Glyceraldehyde-3-phosphate } \\
\text { dehydrogenase } 1\end{array}$ & $35,588 / 6.09$ & 88 & $3(0)$ & 10 & 2.77 & 7.56 \\
\hline 22 & gi|511008895 & $\begin{array}{l}\text { Glyceraldehyde-3-phosphate } \\
\text { dehydrogenase } 1\end{array}$ & $35,588 / 6.09$ & 106 & $2(0)$ & 5 & 8.24 & 13.63 \\
\hline 23 & gi|511008895 & $\begin{array}{l}\text { Glyceraldehyde-3-phosphate } \\
\text { dehydrogenase } 1\end{array}$ & $35,588 / 6.09$ & 394 & $5(3)$ & 15 & 2.50 & 3.50 \\
\hline 24 & gi|511007306 & $\begin{array}{l}\text { Glyceraldehyde-3-phosphate } \\
\text { dehydrogenase } 2\end{array}$ & $36,013 / 5.54$ & 550 & $10(5)$ & 35 & 2.91 & 1.69 \\
\hline 25 & gi|511004614 & Enolase & $47,164 / 5.56$ & 385 & $5(2)$ & 10 & 1.53 & 7.99 \\
\hline 26 & gi|511006733 & Pyruvate kinase & $59,079 / 6.19$ & 464 & $8(3)$ & 18 & 7.59 & 6.44 \\
\hline 27 & gi|511006733 & Pyruvate kinase & $59,079 / 6.19$ & 109 & $4(0)$ & 3 & 4.23 & 3.97 \\
\hline 28 & gi|511004430 & $\begin{array}{l}\text { Pyruvate dehydrogenase } \\
\text { complex }\end{array}$ & $52,323 / 6.11$ & 170 & $2(1)$ & 5 & 17.82 & 1.36 \\
\hline 29 & gi|511004430 & $\begin{array}{l}\text { Pyruvate dehydrogenase } \\
\text { complex }\end{array}$ & $53,161 / 5.76$ & 123 & $2(1)$ & 5 & 21.82 & 4.58 \\
\hline 30 & gi|511005313 & $\begin{array}{l}\text { Pyruvate dehydrogenase E1 } \\
\text { component subunit alpha }\end{array}$ & $43,770 / 8.31$ & 246 & $6(2)$ & 11 & 6.89 & 1.35 \\
\hline 31 & gi|511002644 & $\begin{array}{l}\text { Pyruvate dehydrogenase E2 } \\
\text { component }\end{array}$ & $53,161 / 5.76$ & 183 & $4(1)$ & 8 & 1.93 & 1.51 \\
\hline 32 & gi|511002644 & $\begin{array}{l}\text { Pyruvate dehydrogenase E2 } \\
\text { component }\end{array}$ & $53,161 / 5.76$ & 288 & $4(2)$ & 8 & 50.48 & 21.50 \\
\hline
\end{tabular}


Table 2 continued

\begin{tabular}{|c|c|c|c|c|c|c|c|c|}
\hline Spot & Accession & Protein name & $\begin{array}{l}\text { Theoretical } \\
\mathrm{MW}(\mathrm{Da}) / \mathrm{pl}\end{array}$ & $\begin{array}{l}\text { MASCOT } \\
\text { score }\end{array}$ & $\begin{array}{l}\text { No. } \\
\text { matched }\end{array}$ & $\begin{array}{l}\text { Coverage } \\
(\%)\end{array}$ & $\begin{array}{l}\text { Fold } \\
\text { change } \\
24 \mathrm{~h} / 6 \mathrm{~h}\end{array}$ & $\begin{array}{l}\text { Fold } \\
\text { change } \\
60 \mathrm{~h} / 6 \mathrm{~h}\end{array}$ \\
\hline 33 & gi|511003312 & $\begin{array}{l}\text { 2,3-Bisphosphoglycerate-inde- } \\
\text { pendent phosphoglycerate } \\
\text { mutase }\end{array}$ & $56,737 / 5.23$ & 332 & $8(3)$ & 16 & 0.48 & 0.41 \\
\hline 34 & gi|511003312 & $\begin{array}{l}\text { 2,3-Bisphosphoglycerate-inde- } \\
\text { pendent phosphoglycerate } \\
\text { mutase }\end{array}$ & $56,737 / 5.23$ & 118 & $3(0)$ & 5 & 0.46 & 0.62 \\
\hline 35 & gi|511010411 & $\begin{array}{l}\text { Glucose-6-phosphate dehydro- } \\
\text { genase }\end{array}$ & $58,358 / 6.72$ & 96 & $3(0)$ & 12 & 1.62 & 1.51 \\
\hline 36 & gi|511005381 & Transaldolase & $35,798 / 5.45$ & 137 & $3(0)$ & 9 & 2.64 & 0.71 \\
\hline 37 & gi|511001250 & Transketolase & $74,273 / 5.71$ & 108 & $4(1)$ & 8 & 2.64 & 2.56 \\
\hline 38 & gi|511005018 & $\begin{array}{l}\mathrm{NAD}^{+} \text {:isocitrate dehydrogenase, } \\
\text { mitochondrial }\end{array}$ & $41,006 / 7.02$ & 735 & $11(7)$ & 34 & 0.53 & 0.62 \\
\hline 39 & gi|511005320 & $\begin{array}{l}\mathrm{NADP}^{+} \text {:isocitrate dehydrogenase } \\
\text { mitochondrial }\end{array}$ & $47,644 / 5.97$ & 164 & $4(1)$ & 11 & 0.31 & 0.57 \\
\hline 40 & gi|511002271 & $\begin{array}{l}\text { Succinyl-CoA ligase, mitochon- } \\
\text { drial }\end{array}$ & $47,555 / 5.89$ & 138 & $4(1)$ & 12 & 0.55 & 0.39 \\
\hline 41 & gi|511009244 & Succinate dehydrogenase & $71,166 / 6.15$ & 112 & $3(1)$ & 7 & 0.71 & 0.55 \\
\hline 42 & gi|511006629 & $\begin{array}{l}\text { Fumarate hydratase, mitochon- } \\
\text { drial }\end{array}$ & $53,753 / 6.65$ & 410 & $4(4)$ & 11 & 0.55 & 0.39 \\
\hline 43 & gi|511003684 & Aldehyde dehydrogenase & $54,639 / 5.51$ & 368 & $10(4)$ & 20 & 1.52 & 1.95 \\
\hline 44 & gi|511001067 & Aldehyde dehydrogenase & $53,854 / 5.57$ & 284 & $5(2)$ & 14 & 1.64 & 1.72 \\
\hline 45 & gi|511008662 & Acetyl-CoA C-acetyltransferase & $41,434 / 5.65$ & 507 & $8(4)$ & 23 & 0.39 & 0.43 \\
\hline 46 & gi|511005081 & Phosphoglucomutase & $61,303 / 5.61$ & 151 & $4(1)$ & 11 & 3.50 & 4.55 \\
\hline 47 & gi|511006219 & $\begin{array}{l}\text { UTP-glucose-1-phosphate uridy- } \\
\text { lyltransferase }\end{array}$ & $56,716 / 6.15$ & 655 & $10(3)$ & 23 & 3.21 & 4.01 \\
\hline 48 & gi|511006325 & UDP-glucose 4-epimerase & $39,235 / 5.76$ & 138 & $3(0)$ & 12 & 1.07 & 1.55 \\
\hline 49 & gi|511009038 & Galactokinase & $48,847 / 6.00$ & 209 & $5(0)$ & 12 & 2.17 & 2.26 \\
\hline 50 & gi|511010174 & S-Formylglutathione hydrolase & $32,160 / 6.11$ & 61 & $2(0)$ & 3 & 2.27 & 2.68 \\
\hline 51 & gi|758354396 & Thiazole biosynthetic enzyme & $33,882 / 5.28$ & 345 & $3(1)$ & 18 & 20.96 & 14.71 \\
\hline \multicolumn{9}{|c|}{ Protein metabolism } \\
\hline 52 & gi|511000792 & $40 S$ ribosomal protein $\$ 21$ & $9718 / 4.93$ & 287 & $3(2)$ & 66 & 0.34 & 0.35 \\
\hline 53 & gi|511011908 & 405 ribosomal protein S7 & $21,057 / 9.70$ & 71 & $1(1)$ & 12 & 0.07 & 0.12 \\
\hline 54 & gi|511008091 & $\begin{array}{l}\text { Eukaryotic translation initiation } \\
\text { factor } 5 \mathrm{~A}\end{array}$ & $17,694 / 5.08$ & 302 & $3(3)$ & 19 & 0.13 & 0.68 \\
\hline 55 & gi|511011759 & Elongation factor Tu & $51,841 / 6.26$ & 294 & $5(2)$ & 13 & 0.17 & 0.09 \\
\hline 56 & gi|511006438 & $\begin{array}{l}\text { Nascent polypeptide-associated } \\
\text { complex subunit beta }\end{array}$ & $17,501 / 5.34$ & 362 & $5(3)$ & 48 & 0.02 & 0.06 \\
\hline 57 & gi|511003551 & $\begin{array}{l}\text { 26S protease regulatory subunit } \\
6 \mathrm{~A}\end{array}$ & $48,455 / 4.96$ & 346 & $9(2)$ & 18 & 0.29 & 0.33 \\
\hline 58 & gi|511009637 & $\begin{array}{l}\text { 26S protease regulatory subunit } \\
6 \mathrm{~B}\end{array}$ & $46,545 / 5.72$ & 228 & $4(2)$ & 15 & 0.42 & 0.38 \\
\hline 59 & gi|511010098 & 205 proteasome subunit Alpha 6 & $31,144 / 5.06$ & 254 & $4(2)$ & 15 & 0.01 & 0.02 \\
\hline \multicolumn{9}{|c|}{ Nucleic acid metabolism } \\
\hline 60 & gi|511005974 & $\begin{array}{l}\text { Phosphoribosylaminoimidazole- } \\
\text { succinocarboxamide synthase }\end{array}$ & $33,792 / 5.10$ & 231 & $3(2)$ & 11 & 0.49 & 0.60 \\
\hline 61 & gi|511011778 & Adenylyl-sulfate kinase & $22,883 / 5.75$ & 387 & $8(2)$ & 32 & 0.20 & 0.12 \\
\hline 62 & gi|511006145 & $\begin{array}{l}\text { Dihydroorotase, homodimeric } \\
\text { type }\end{array}$ & $39,652 / 5.83$ & 233 & $5(0)$ & 13 & 0.43 & 0.45 \\
\hline \multicolumn{9}{|c|}{ Energy metabolism } \\
\hline 63 & gi|511006698 & Adenylate kinase 1 & $28,268 / 7.01$ & 624 & $10(6)$ & 51 & 1.61 & 2.53 \\
\hline 64 & gi|511006698 & Adenylate kinase 1 & $28,268 / 7.01$ & 571 & $8(5)$ & 29 & 37.78 & 20.29 \\
\hline
\end{tabular}


Table 2 continued

\begin{tabular}{|c|c|c|c|c|c|c|c|c|}
\hline Spot & Accession & Protein name & $\begin{array}{l}\text { Theoretical } \\
\mathrm{MW}(\mathrm{Da}) / \mathrm{pl}\end{array}$ & $\begin{array}{l}\text { MASCOT } \\
\text { score }\end{array}$ & $\begin{array}{l}\text { No. } \\
\text { matched }\end{array}$ & $\begin{array}{l}\text { Coverage } \\
(\%)\end{array}$ & $\begin{array}{l}\text { Fold } \\
\text { change } \\
24 \mathrm{~h} / 6 \mathrm{~h}\end{array}$ & $\begin{array}{l}\text { Fold } \\
\text { change } \\
60 \mathrm{~h} / 6 \mathrm{~h}\end{array}$ \\
\hline 65 & gi|511003961 & $\begin{array}{l}\text { V-type } \mathrm{H}+\text {-transporting ATPase } \\
\text { subunit I }\end{array}$ & $95,461 / 5.05$ & 193 & $3(1)$ & 5 & 1.61 & 1.51 \\
\hline 66 & gi|511007631 & $\begin{array}{l}\text { V-type proton ATPase catalytic } \\
\text { subunit A }\end{array}$ & $70,756 / 5.07$ & 361 & $6(3)$ & 15 & 3.23 & 1.72 \\
\hline \multicolumn{9}{|c|}{ Signal transduction } \\
\hline 67 & gi|511007036 & 14-3-3 family protein epsilon & $29,228 / 4.84$ & 175 & $5(1)$ & 24 & 1.75 & 2.01 \\
\hline \multicolumn{9}{|c|}{ Molecular chaperone } \\
\hline 68 & gi|511004981 & Heat shock $70 \mathrm{kDa}$ protein 1/8 & $67,760 / 5.10$ & 280 & $3(2)$ & 7 & 4.23 & 3.64 \\
\hline 69 & gi|511004335 & Hsp70-like protein & $71,389 / 5.79$ & 202 & $4(1)$ & 7 & 2.38 & 2.99 \\
\hline 70 & gi|511003138 & $\begin{array}{l}\text { Peptidyl-prolyl cis-trans isomer- } \\
\text { ase cyp5 }\end{array}$ & $19,078 / 6.92$ & 477 & $8(5)$ & 47 & 1.72 & 1.64 \\
\hline \multicolumn{9}{|c|}{ Redox homeostasis } \\
\hline 71 & gi|511008071 & Peroxiredoxin & $22,926 / 4.94$ & 254 & $3(2)$ & 25 & 20.46 & 2.95 \\
\hline 72 & gi|511008071 & Peroxiredoxin & $22,926 / 4.94$ & 114 & $2(1)$ & 12 & 15.30 & 13.16 \\
\hline 73 & gi|511008071 & Peroxiredoxin & $22,926 / 4.94$ & 173 & $3(1)$ & 14 & 16.70 & 17.01 \\
\hline 74 & gi|503389911 & Glutathione peroxidase & $20,881 / 6.40$ & 61 & $1(0)$ & 5 & 1.58 & 3.42 \\
\hline 75 & gi|511008344 & Oxidoreductase & $30,743 / 6.25$ & 432 & $5(2)$ & 15 & 1.55 & 3.44 \\
\hline 76 & gi|511009098 & Oxidoreductase & $28,164 / 6.54$ & 310 & $6(2)$ & 28 & 1.84 & 1.66 \\
\hline 77 & gi|511009792 & Ferritin heavy chain & $20,301 / 5.23$ & 268 & $5(3)$ & 39 & 2.30 & 2.08 \\
\hline \multicolumn{9}{|c|}{ Hypothetical protein } \\
\hline 78 & gi|511011920 & $\begin{array}{l}\text { Hypothetical protein } \\
\text { HMPREF1544_00199 }\end{array}$ & $91,261 / 6.42$ & 211 & $5(1)$ & 5 & 23.83 & 8.50 \\
\hline 79 & gi|511010665 & $\begin{array}{l}\text { Hypothetical protein } \\
\text { HMPREF1544_01177 }\end{array}$ & $55,006 / 4.72$ & 85 & $2(1)$ & 6 & 4.84 & 2.65 \\
\hline 80 & gi|511010454 & $\begin{array}{l}\text { Hypothetical protein } \\
\text { HMPREF1544_01386 }\end{array}$ & $28,881 / 6.42$ & 101 & $2(0)$ & 6 & 41.34 & 58.10 \\
\hline 81 & gi|511009952 & $\begin{array}{l}\text { Hypothetical protein } \\
\text { HMPREF1544_01888 }\end{array}$ & $14,839 / 5.89$ & 125 & $1(1)$ & 10 & 4.23 & 2.59 \\
\hline 82 & gi|511009952 & $\begin{array}{l}\text { Hypothetical protein } \\
\text { HMPREF1544_01888 }\end{array}$ & $14,839 / 5.89$ & 293 & $3(2)$ & 32 & 3.18 & 1.74 \\
\hline 83 & gi|511009799 & $\begin{array}{l}\text { Hypothetical protein } \\
\text { HMPREF1544_02101 }\end{array}$ & $47,569 / 7.79$ & 191 & $3(2)$ & 10 & 0.35 & 0.43 \\
\hline 84 & gi|511009692 & $\begin{array}{l}\text { Hypothetical protein } \\
\text { HMPREF1544_02181 }\end{array}$ & $22,351 / 5.33$ & 175 & $3(2)$ & 13 & 23.25 & 37.32 \\
\hline 85 & gi|511009605 & $\begin{array}{l}\text { Hypothetical protein } \\
\text { HMPREF1544_02260 }\end{array}$ & $26,248 / 5.37$ & 175 & $3(1)$ & 12 & 9.70 & 3.04 \\
\hline 86 & gi|511008946 & $\begin{array}{l}\text { Hypothetical protein } \\
\text { HMPREF1544_03035 }\end{array}$ & $42,241 / 7.22$ & 630 & $8(4)$ & 26 & 34.49 & 15.14 \\
\hline 87 & gi|511008765 & $\begin{array}{l}\text { Hypothetical protein } \\
\text { HMPREF1544_03136 }\end{array}$ & $53,353 / 5.77$ & 422 & $5(4)$ & 15 & 0.06 & 0.07 \\
\hline 88 & gi|511008618 & $\begin{array}{l}\text { Hypothetical protein } \\
\text { HMPREF1544_03262 }\end{array}$ & $68,758 / 6.29$ & 378 & $7(3)$ & 12 & 0.01 & 0.01 \\
\hline 89 & gi|511008350 & $\begin{array}{l}\text { Hypothetical protein } \\
\text { HMPREF1544_03549 }\end{array}$ & $43,856 / 7.82$ & 229 & $4(2)$ & 9 & 13.89 & 17.99 \\
\hline 90 & gi|511008286 & $\begin{array}{l}\text { Hypothetical protein } \\
\text { HMPREF1544_03639 }\end{array}$ & $48,153 / 5.50$ & 235 & $5(2)$ & 10 & 0.11 & 0.25 \\
\hline 91 & gi|511008150 & $\begin{array}{l}\text { Hypothetical protein } \\
\text { HMPREF1544_03790 }\end{array}$ & $20,026 / 5.04$ & 307 & $4(2)$ & 22 & 0.16 & 0.34 \\
\hline 92 & gi|511008020 & $\begin{array}{l}\text { Hypothetical protein } \\
\text { HMPREF1544_03919 }\end{array}$ & 29,429/6.97 & 425 & $6(4)$ & 37 & 0.20 & 0.19 \\
\hline 93 & gi|511007940 & $\begin{array}{l}\text { Hypothetical protein } \\
\text { HMPREF1544_03956 }\end{array}$ & $29,843 / 5.14$ & 123 & $2(1)$ & 10 & 25.34 & 20.07 \\
\hline
\end{tabular}


Table 2 continued

\begin{tabular}{|c|c|c|c|c|c|c|c|c|}
\hline Spot & Accession & Protein name & $\begin{array}{l}\text { Theoretical } \\
\text { MW (Da)/pl }\end{array}$ & $\begin{array}{l}\text { MASCOT } \\
\text { score }\end{array}$ & $\begin{array}{l}\text { No. } \\
\text { matched }\end{array}$ & $\begin{array}{l}\text { Coverage } \\
(\%)\end{array}$ & $\begin{array}{l}\text { Fold } \\
\text { change } \\
24 \mathrm{~h} / 6 \mathrm{~h}\end{array}$ & $\begin{array}{l}\text { Fold } \\
\text { change } \\
60 \mathrm{~h} / 6 \mathrm{~h}\end{array}$ \\
\hline 94 & gi|511007175 & $\begin{array}{l}\text { Hypothetical protein } \\
\text { HMPREF1544_04707 }\end{array}$ & $63,905 / 5.35$ & 106 & $2(0)$ & 4 & 0.09 & 0.09 \\
\hline 95 & gi|511006887 & $\begin{array}{l}\text { Hypothetical protein } \\
\text { HMPREF1544_05024 }\end{array}$ & $55,228 / 6.28$ & 275 & $3(2)$ & 9 & 2.16 & 5.78 \\
\hline 96 & gi|511006887 & $\begin{array}{l}\text { Hypothetical protein } \\
\text { HMPREF1544_05024 }\end{array}$ & $55,228 / 6.28$ & 309 & $5(2)$ & 10 & 5.47 & 5.35 \\
\hline 97 & gi|511006017 & $\begin{array}{l}\text { Hypothetical protein } \\
\text { HMPREF1544_05863 }\end{array}$ & $30,010 / 5.58$ & 423 & $4(4)$ & 23 & 2.45 & 2.18 \\
\hline 98 & gi|511004978 & $\begin{array}{l}\text { Hypothetical protein } \\
\text { HMPREF1544_06871 }\end{array}$ & $18,967 / 4.96$ & 249 & $3(2)$ & 13 & 5.27 & 17.90 \\
\hline 99 & gi|511004902 & $\begin{array}{l}\text { Hypothetical protein } \\
\text { HMPREF1544_06986 }\end{array}$ & $28,947 / 9.05$ & 103 & $1(1)$ & 6 & 3.61 & 2.41 \\
\hline 100 & gi|511004522 & $\begin{array}{l}\text { Hypothetical protein } \\
\text { HMPREF1544_07306 }\end{array}$ & $26,114 / 5.56$ & 252 & $4(2)$ & 21 & 7.99 & 3.58 \\
\hline 101 & gi|511004398 & $\begin{array}{l}\text { Hypothetical protein } \\
\text { HMPREF1544_07438 }\end{array}$ & $21,313 / 5.70$ & 199 & $3(1)$ & 13 & 0.29 & 0.18 \\
\hline 102 & gi|511004099 & $\begin{array}{l}\text { Hypothetical protein } \\
\text { HMPREF1544_07752 }\end{array}$ & $21,249 / 5.14$ & 294 & $6(2)$ & 31 & 24.54 & 3.86 \\
\hline 103 & gi|511003967 & $\begin{array}{l}\text { Hypothetical protein } \\
\text { HMPREF1544_07893 }\end{array}$ & $16,356 / 4.59$ & 152 & $3(1)$ & 30 & 0.04 & 0.20 \\
\hline 104 & gi|511003188 & $\begin{array}{l}\text { Hypothetical protein } \\
\text { HMPREF1544_08616 }\end{array}$ & $30,249 / 5.39$ & 224 & $4(1)$ & 11 & 28.24 & 26.23 \\
\hline 105 & gi|511003039 & $\begin{array}{l}\text { Hypothetical protein } \\
\text { HMPREF1544_08758 }\end{array}$ & $19,098 / 8.39$ & 392 & $4(3)$ & 25 & 4.40 & 2.25 \\
\hline 106 & gi|511003039 & $\begin{array}{l}\text { Hypothetical protein } \\
\text { HMPREF1544_08758 }\end{array}$ & $19,098 / 8.39$ & 347 & $8(2)$ & 70 & 8.61 & 9.91 \\
\hline 107 & gi|511002615 & $\begin{array}{l}\text { Hypothetical protein } \\
\text { HMPREF1544_09175 }\end{array}$ & $26,203 / 5.36$ & 170 & $4(1)$ & 22 & 6.71 & 3.31 \\
\hline 108 & gi|511002606 & $\begin{array}{l}\text { Hypothetical protein } \\
\text { HMPREF1544_09235 }\end{array}$ & $58,903 / 4.89$ & 98 & $1(1)$ & 5 & 23.78 & 30.46 \\
\hline 109 & gi|511002606 & $\begin{array}{l}\text { Hypothetical protein } \\
\text { HMPREF1544_09235 }\end{array}$ & $58,903 / 4.89$ & 81 & $2(0)$ & 5 & 5.99 & 20.72 \\
\hline 110 & gi|511001781 & $\begin{array}{l}\text { Hypothetical protein } \\
\text { HMPREF1544_10038 }\end{array}$ & $43,811 / 6.02$ & 96 & $1(1)$ & 4 & 8.25 & 14.78 \\
\hline 111 & gi|511001506 & $\begin{array}{l}\text { Hypothetical protein } \\
\text { HMPREF1544_10287 }\end{array}$ & $14,404 / 4.95$ & 156 & $3(0)$ & 26 & 24.12 & 22.30 \\
\hline 112 & gi|511001144 & $\begin{array}{l}\text { Hypothetical protein } \\
\text { HMPREF1544_10622 }\end{array}$ & $24,389 / 5.25$ & 162 & $3(1)$ & 15 & 5.08 & 4.08 \\
\hline 113 & gi|511001065 & $\begin{array}{l}\text { Hypothetical protein } \\
\text { HMPREF1544_10686 }\end{array}$ & $38,562 / 6.58$ & 161 & $5(0)$ & 20 & 26.39 & 17.31 \\
\hline 114 & gi|511000884 & $\begin{array}{l}\text { Hypothetical protein } \\
\text { HMPREF1544_10852 }\end{array}$ & $100,320 / 8.41$ & 161 & $3(1)$ & 5 & 0.04 & 0.00 \\
\hline 115 & gi|511000884 & $\begin{array}{l}\text { Hypothetical protein } \\
\text { HMPREF1544_10852 }\end{array}$ & $100,320 / 8.41$ & 484 & $6(4)$ & 10 & 0.04 & 0.01 \\
\hline 116 & gi|511000884 & $\begin{array}{l}\text { Hypothetical protein } \\
\text { HMPREF1544_10852 }\end{array}$ & $10,0320 / 8.41$ & 210 & $4(1)$ & 7 & 0.01 & 0.02 \\
\hline 117 & gi|511000397 & $\begin{array}{l}\text { Hypothetical protein } \\
\text { HMPREF1544_11327 }\end{array}$ & $66,634 / 5.41$ & 127 & $3(0)$ & 8 & 24.47 & 16.26 \\
\hline 118 & gi|511000331 & $\begin{array}{l}\text { Hypothetical protein } \\
\text { HMPREF1544_11393 }\end{array}$ & $14,081 / 6.75$ & 138 & $3(1)$ & 38 & 2.61 & 3.05 \\
\hline
\end{tabular}

15) take part in serine degradation and glycine cleavage system $\mathrm{T}$ protein (spot 15) is involved in glycine degradation [34]. 3-deoxy-7-phosphoheptulonate synthase (spot
16) is responsible for the biosynthesis of phenylalanine, tyrosine, and tryptophan. These above proteins related to metabolism of amino acids were also down-regulated 
upon $\mathrm{N}$ depletion. Decreased expression of the proteins associated with amino acid metabolism indicated that amino acid biosynthesis was at least partially inhibited due to the absence of nitrogen. In these proteins related to amino acid metabolism, one exception to the overall decreased expression was $S$-adenosylmethionine synthase (SAS, spots 17 and 18) which participates in the biosynthesis of $S$-adenosylmethionine, which is a precursor of glutathione and other methylated cell components [35].

$\mathrm{N}$ deprivation can result in a metabolic imbalance of reactive oxygen species (ROS) and an excess of oxygen radicals [36], while glutathione can quench free radicals and then improve the resistance of the cells to this stress [37]. Therefore, the increased expression of SAS could play a role in providing glutathione to improve stress resistance arising during $\mathrm{N}$ deficiency.

\section{Carbon metabolism}

Carbon metabolism and flux are critical to lipid accumulation. M. circinelloides can grow well and accumulate abundant lipids using glucose as the single carbon source $[6,10,24,38]$. The differential expression of proteins involved in central carbon metabolism pathway is shown in Fig. 3.

The glycolytic pathway provides pyruvate, a key precursor for acetyl-CoA, which is the substrate for fatty acid biosynthesis. Fructose-bisphosphate aldolase (FBA, spots 19 and 20), an essential enzyme involved in glycolysis that catalyzes a reversible cleavage reaction of fructose 1,6-bisphosphate into glyceraldehyde 3-phosphate (G3P) and dihydroxyacetone phosphate (DHAP) [39], was up-regulated under $\mathrm{N}$ deficiency. The increased FBA activity could stimulate glycolysis and triacylglycerol biosynthesis. Glyceraldehyde-3-phosphate dehydrogenase (spots 21, 22, 23 and 24), enolase (spots 25) and pyruvate kinase (spots 26 and 27), which are key enzymes in the glycolytic pathway, were also up-regulated under $\mathrm{N}$ deficiency. Up-regulation of these proteins may also lead to the increased production of pyruvate. In addition, the expression of pyruvate dehydrogenase (PDH, spots 28, 29, 30, 31 and 32) was increased and thus lead to increased conversion of pyruvate into acetyl-CoA in the mitochondrion. Taken together, under $\mathrm{N}$ deficiency, the expression of many proteins involved in glycolytic pathway was increased, which would then provide more acetyl-CoA in the mitochondrion.

Phosphoglycerate mutase (PGM, spots 33 and 34) is also involved in glycolysis, catalyzing the interconversion of 3-phosphoglycerate (3PGA) to 2-phosphoglycerate (2PGA). In this study, PGM was down-regulated when the fungus was grown under $\mathrm{N}$ deficient condition, as FBA was up-regulated, the expression changes of these proteins could lead to accumulation of some intermediate between fructose-1,6-bisphosphate and 3-phosphoglyceric acid and this could be glycerol.

The pentose phosphate pathway (PPP) generates $\mathrm{NADPH}$, which is an important source besides malic enzyme (ME) for providing reducing power for fatty acid biosynthesis [2]. In this study, glucose-6-phosphate dehydrogenase (G6PDH, spot 35), which is a key enzyme in the PPP that generates NADPH, was up-regulated under $\mathrm{N}$ deficiency. This is in accordance with our previous report showing that lipid accumulation in $M$. circinelloides is accompanied by increased G6PDH activity after $\mathrm{N}$ depletion from the medium [6]. Furthermore, transaldolase (spot 36) and transketolase (spot 37), as part of the PPP, were both up-regulated. These results indicated that PPP was more active during the lipid accumulation phase after $\mathrm{N}$ depletion, and this would provide more NADPH for fatty acid biosynthesis. For ME, the critical enzyme plays a key role in supplying NADPH for fatty acid synthesis and desaturation in $M$. circinelloides [10,38, 40,41], we did not find any change in its expression at proteomic level upon $\mathrm{N}$ deficiency, which indicates the ME gene is being expressed all the time, irrespective of the status of the cells, and regulation of ME maybe complicated.

Oleaginous yeasts deaminate AMP to release ammonium and IMP upon nitrogen limitation [3]. $\mathrm{NAD}^{+}$:isocitrate dehydrogenase $\left(\mathrm{NAD}^{+}: \mathrm{ICDH}\right)$ requires AMP for activity. With ICDH activity being curtailed by the lack of AMP, isocitrate accumulates and equilibrates back to citrate which is then transported out of the mitochondrion into the cytosol, and thus provides the increased carbon flux to acetyl-CoA for fatty acid synthesis [5]. In this study, the $\mathrm{NAD}^{+}: \mathrm{ICDH}$ (spot 38) was down-regulated upon $\mathrm{N}$ deficiency which would increase citrate accumulation and then lead to greater carbon flux to acetyl-CoA for fatty acid synthesis. Mitochondrial $\mathrm{NADP}^{+}: \mathrm{ICDH}$ (spot 39) was also down-regulated, and this regulation was similar to $\mathrm{NAD}^{+}: \mathrm{ICDH}$. In addition, the expression of some other proteins (e.g., succinyl-CoA ligase, spot 40; succinate dehydrogenase, spot 41; fumarate hydratase, spot 42) involved in TCA cycle were all decreased, and this further suggests that the TCA cycle is retarded upon $\mathrm{N}$ deficiency which will therefore lead to a greater carbon flux to lipids biosynthesis. These results are well in accordance with our previous studies of lipid accumulation in $M$. circinelloides and the multi-omic analysis of lipid accumulation in Rhodosporidium toruloides by Zhu et al. $[6,12]$.

Aldehyde dehydrogenase (ALDH, spots 43 and 44), which converts acetaldehyde into acetate, was up-regulated upon $\mathrm{N}$ deficiency. Although in oleaginous fungi and higher eukaryotes, the major route of acetyl-CoA 


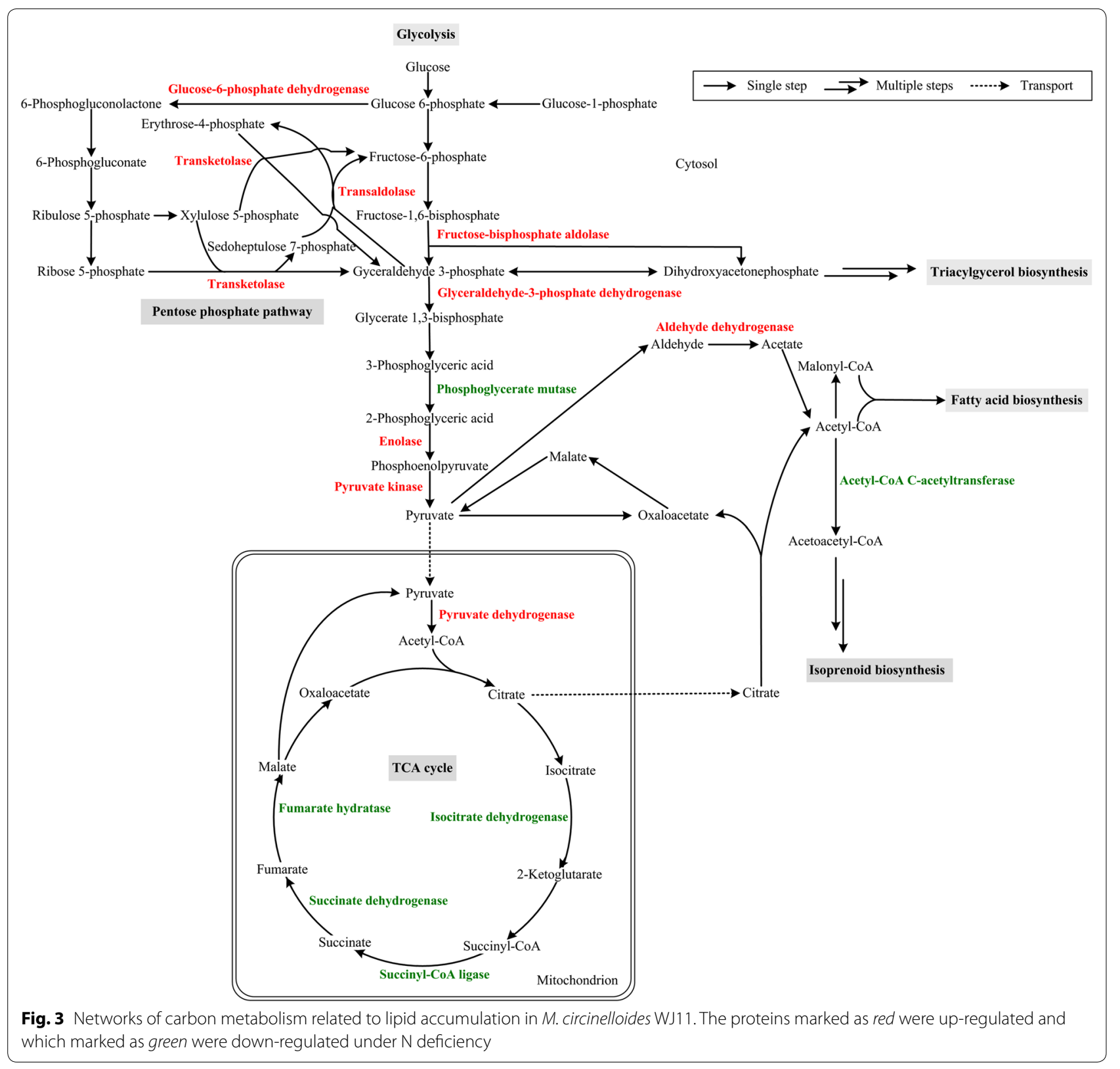

production is by the cleavage of citrate by ATP:citrate lyase (ACL) [7], it can also be produced by cytoplasmic acetyl-CoA synthase (ACS) from acetate when acetate is being produced by the degradation of proteins and amino acids that are surplus to the requirements of the cell. The level of acetyl-CoA C-acetyltransferase (ACAT, spot 187), which is the branch point enzyme for acetyl-CoA to synthesize isoprenoids, was decreased under $\mathrm{N}$ deficiency which indicates that the acetyl-CoA flux is being preferentially switched into the synthesis of fatty acids but not into isoprenoids.

Galactokinase (spot 49) catabolizes $\beta$-D-galactose to glucose 1-phosphate. Phosphoglucomutase (spot 46) facilitates the interconversion of glucose 1-phosphate and glucose 6-phosphate. UTP-glucose-1-phosphate uridylyltransferase (spot 47) synthesizes UDP-glucose from glucose-1-phosphate. UDP-glucose 4-epimerase (spot 48) catalyzes the reversible conversion of UDP-galactose to UDP-glucose. These proteins are involved in galactose and glucose conversion into polysaccharides and were all up-regulated upon $\mathrm{N}$ deficiency, suggesting that glucose utilization of the fungus might be sequentially proceeded during lipid accumulation triggered by $\mathrm{N}$ depletion.

$S$-Formylglutathione hydrolase (spot 50) can produce glutathione from hydrolysis of $S$-formylglutathione and its expression was up-regulated upon $\mathrm{N}$ deficiency. $\mathrm{N}$ 
deprivation can result in an excess of oxygen radicals and glutathione can quench free radicals [42]. Therefore the up-regulated protein could be a stress response to $\mathrm{N}$ deficiency. Thiazole biosynthetic enzyme (TBE, spot 51) associated with thiamine metabolism was also upregulated upon $\mathrm{N}$ depletion. It plays additional roles in adaptation to various stress conditions and in DNA damage tolerance $[43,44]$. Thus the increased expression of $\mathrm{TBE}$ in the fungus is likely the cellular adaptation to $\mathrm{N}$ depletion.

\section{Other metabolism}

As de novo protein biosynthesis is no longer occurring after $\mathrm{N}$ deficiency, then the cell must conserve its key proteins for as long as possible. Thus, the expression of proteins (spots 52-59) related to protein metabolism were diminished in the fungus under $\mathrm{N}$ deficient conditions. In addition, the expression of proteins involved in nucleic acid metabolism (spots 60, 61 and 62) were also decreased and this further indicates that cell reproduction and growth are decreased upon $\mathrm{N}$ depletion [19].

The activity of adenylate kinase has been found to be stimulated after N-exhaustion in M. circinelloides [45] and we found that, in accordance with this, the expression of adenylate kinase (spots 63 and 64) was increased upon $\mathrm{N}$ deficiency. Furthermore, ATPase (spots 65 and 66) was also up-regulated. The metabolic pattern of M. circinelloides is therefore readjusted when $\mathrm{N}$ becomes exhausted in the medium. In $M$. circinelloides, the concentrations of ATP, ADP and AMP decrease at the time of N-exhaustion so that energy, in the form of ATP, is now produced at a lower level $[20,45]$. Therefore the increased expression of adenylate kinase and ATPase might play a role in helping to maintain energy production.

14-3-3 Family protein epsilon (spot 67) can restrain cell apoptosis and promote cell survival under stress condition [46] and the increased expression in N limitation could be the cellular response to $\mathrm{N}$ deficiency. Heat shock proteins (HSPs) are a group of functionally related proteins responsible for protein folding and unfolding. High-level expression of HSPs can be triggered by exposure to different environmental stress conditions, including exposure of the cell to nitrogen deficiency [47]. We identified similar trends in $\mathrm{N}$-deprived cells, including two HSPs (spots 68 and 69), which were significantly up-regulated. Peptidyl-prolyl cis-trans isomerase plays roles in protein folding and transport, RNA splicing and the regulation of multi-protein complexes in cells [48]. In this study, expression of this protein (spot 70) was upregulated in $\mathrm{N}$ deprivation, and this might also be part of the cellular adaption to stress conditions engendered by $\mathrm{N}$ deficiency.
Excessive generation of ROS or oxidative stress is an integral part of many stress situations, including $\mathrm{N}$ limitation [36]. Peroxiredoxin (Prx) is a ubiquitous family of antioxidant enzymes and glutathione peroxidase (GPx) has the biological role in protecting organism from oxidative damage. Indeed, the $\operatorname{Prx}$ (spots 71, 72 and 73) and GPx (spot 74) were up-regulated upon $\mathrm{N}$ deficiency. The increased expression of an oxidoreductase (spots 75 and 76) that catalyzes the transfer of electrons from reductant to oxidant is also a response to oxidative stress upon $\mathrm{N}$ limitation. Ferritin heavy chain (spot 77), a ubiquitous and highly conserved protein, which plays a major role in iron homeostasis, was also up-regulated upon $\mathrm{N}$ deficiency. Many haem-proteins would be degraded as being surplus to the requirements of the cell during $\mathrm{N}$ deprivation. The iron being released from these proteins and other non-haem iron proteins will therefore be scavenged by the cell and stored intracellularly in ferritin. This may lead to the increased expression of ferritin heavy chain.

\section{Analysis of the transcription of selected genes by quantitative RT-PCR}

Some differentially expressed proteins that participate in key metabolic reactions related to lipid accumulation during the bioprocess, G6PDH, PDH, NAD ${ }^{+}: \mathrm{ICDH}$ and acetyl-CoA C-acetyltransferase (ACAT), were selected to determine the transcription levels of their genes by quantitative RT-PCR. These proteins are encoded by more than one gene and the mRNA expression profiles of these genes are shown in Fig. 4. G6PDH is encoded by four genes and the transcription levels of $g 6 p d h 1$ and $g 6 p d h 2$ were significantly higher at $24 \mathrm{~h}$ and $60 \mathrm{~h}$ of growth (lipid accumulation phase) than at $6 \mathrm{~h}$ of growth (balanced growth phase), which is in accordance with the protein expression level in this study and the enzymatic activity in M. circinellodies of our previous research [6]. Therefore the $g 6 p d h 1$ and $g 6 p d h 2$ might play an important role (e.g., supply of NADPH for fatty acids) in lipid accumulation. Unlike $g 6 p d h 1$ and $g 6 p d h 2$, the transcription levels of $g 6 p d h 3$ and $g 6 p d h 4$ were stable during the whole bioprocess.

The mRNA of the genes encoding PDH were increased upon $\mathrm{N}$ deficiency. This is coincident with expression level of the protein, suggesting that conversion of pyruvate to acetyl CoA for TCA cycle was increased upon $\mathrm{N}$ depletion. Transcription levels of the genes encoding $\mathrm{NAD}^{+}$:ICDH were decreased upon $\mathrm{N}$ depletion indicating that TCA cycle is retarded after $\mathrm{N}$ exhaustion. Thus, the combined coordinated regulation of PDH and $\mathrm{NAD}^{+}: \mathrm{ICDH}$ upon $\mathrm{N}$ depletion results in an increased cytosolic acetyl-CoA production for fatty acid biosynthesis. Furthermore, the mRNA of the genes encoding 


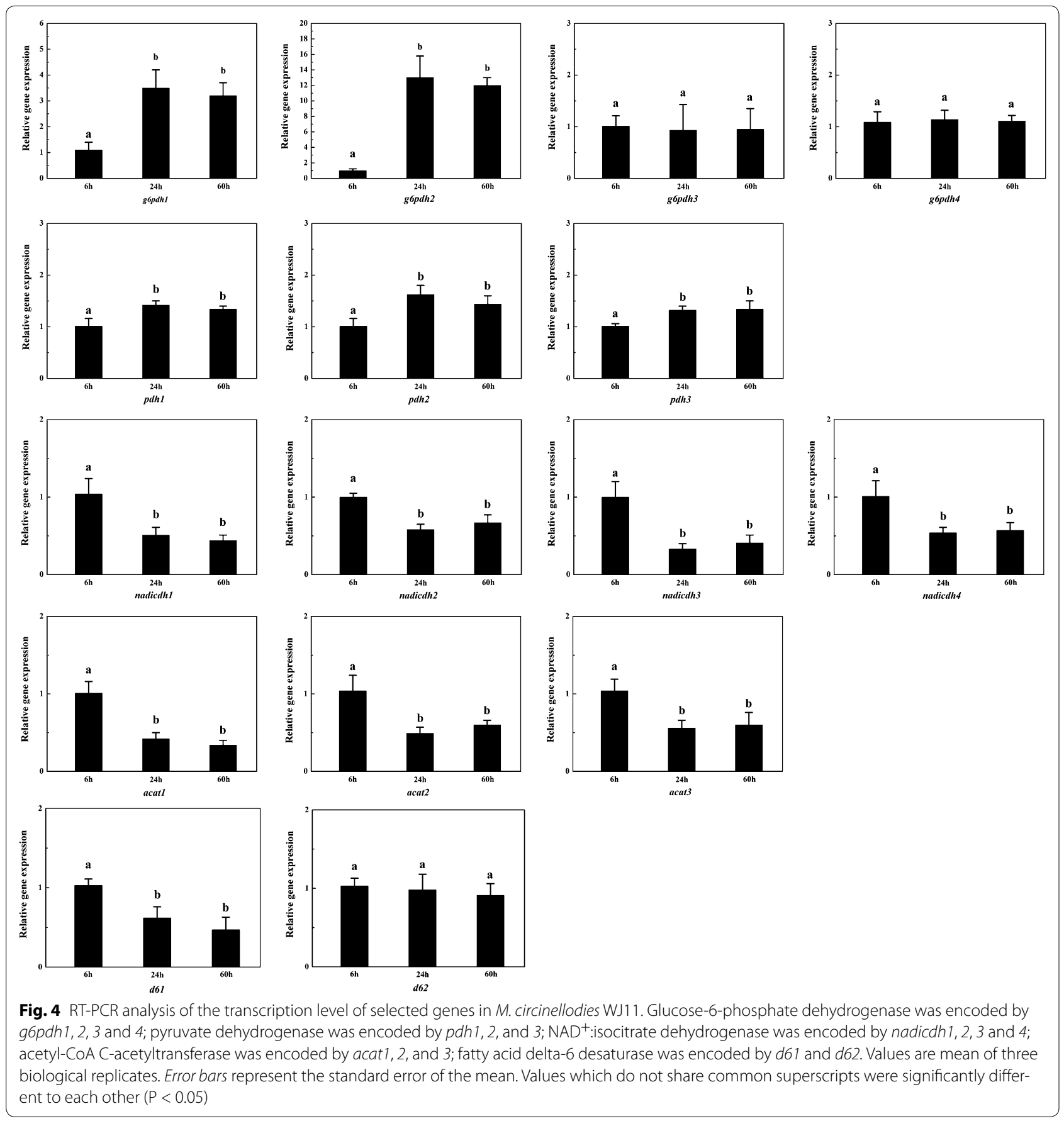

ACAT were also decreased upon $\mathrm{N}$ limitation, which is in according with its protein level. This will direct the flux of acetyl-CoA into fatty acid biosynthesis rather than into isoprenoid biosynthesis. Taken together, the quantitative RT-PCR analysis demonstrated the transcription level of some proteins related to lipid accumulation under $\mathrm{N}$ deficiency is consistant with their protein level from proteomic data.
M. circinelloides is a GLA-producing filamentous fungus and fatty acid delta- 6 desaturase converts linoleic acid into GLA, which is an key enzyme for GLA biosynthesis [49]. Thus we also investigated transcription levels of the genes ( $d 61$ and $d 62$ ) encoding fatty acid delta- 6 desaturase (Fig. 4). The result showed the transcription level of $d 61$ was significantly lower at $24 \mathrm{~h}$ and $60 \mathrm{~h}$ than that at $6 \mathrm{~h}$, while the level of $d 62 \mathrm{had}$ no obvious changes 
in whole bioprocess. The fatty acid composition showed the GLA content in total fatty acid at $24 \mathrm{~h}$ and $60 \mathrm{~h}$ were both less than half of that at $6 \mathrm{~h}$ (Additional file 1: Table S1), which was in according with the transcription level of $d 61$.

\section{Conclusion}

This study represents a proteomic analysis of lipid accumulation in M. circinelloides WJ11, a higher lipid-producing strain (36 \% lipid, w/w), grown under $\mathrm{N}$ limited condition. $\mathrm{N}$ limitation increased the expression of the proteins involved in ammonia assimilation for the supply of cellular nitrogen but decreased the expression of proteins involved in the biosynthesis of amino acids. Carbon metabolism is crucial for lipid accumulation, which was significantly affected upon $\mathrm{N}$ deficiency. Upon $\mathrm{N}$ deprivation, the glycolysis pathway, which provides pyruvate, a key precursor for acetyl-CoA, was up-regulated, while the activity of the TCA cycle was retarded, thus, leading more carbon flux to fatty acid biosynthesis. Moreover, there is some evidence that the PPP was up-regulated and then this would increase the production of NADPH needed for fatty acid biosynthesis. Together, coordinated regulation of central carbon metabolism upon $\mathrm{N}$ limitation, provide more carbon flux to acetyl-CoA and NADPH for fatty acid biosynthesis. In addition, protein and nucleic acid metabolism was down-regulated upon $\mathrm{N}$ limitation, this shifts the cellular metabolism to lipid biosynthesis. Also, some protein involved in energy metabolism, signal transduction, molecular chaperone and redox homeostasis were up-regulated in response to stress condition of $\mathrm{N}$ deficiency.

\section{Methods}

\section{Microorganism and cultivation}

M. circinelloides WJ11 isolated in our laboratory from soil at Jiangnan University was used in this study [6, 49]. $100 \mu \mathrm{l}$ spore suspension (approx. $10^{7}$ spores $/ \mathrm{mL}$ ) of M. circinelloides WJ11 was cultivated in $150 \mathrm{~mL} \mathrm{~K}$ \& R medium [38] held in $1 \mathrm{~L}$ flasks equipped with baffles for $24 \mathrm{~h}$ with shaking at $150 \mathrm{rpm}$ and $30^{\circ} \mathrm{C}$, and then used at $10 \%(\mathrm{v} / \mathrm{v})$ to inoculate $2 \mathrm{~L}$ fermenters containing 1.5 $\mathrm{L}$ modified $\mathrm{K} \& \mathrm{R}$ medium (80 g glucose and $2 \mathrm{~g}$ diammonium tartrate per liter). Fermenters were controlled at $30{ }^{\circ} \mathrm{C}$ with stirring at $700 \mathrm{rpm}$ and aeration at $0.5 \mathrm{v} / \mathrm{v}$ $\min ^{-1}$. The $\mathrm{pH}$ was maintained at 6.0 by auto-addition of $4 \mathrm{M} \mathrm{KOH}$ or $2 \mathrm{M} \mathrm{H}_{2} \mathrm{SO}_{4}$.

\section{Analysis of cell dry weight (CDW), culture supernatant and lipid accumulation}

Biomass was periodically harvested by filtration using a dried and pre-weighed filter paper and a Buchner funnel under vacuum and washed three times with distilled water, frozen overnight at $-80{ }^{\circ} \mathrm{C}$ and then freeze-dried. The weight of dry cells was determined gravimetrically. Glucose concentration in the culture medium was measured using a glucose oxidase kit according to the manufacturer's instructions. Ammonium concentration in the culture filtrate was determined using the indophenol test [50]. Total lipid was extracted and analyzed by the procedure reported in our previous work [6].

\section{Protein extraction for two-dimensional electrophoresis (2-DE)}

Cells taken from the balanced phase of growth (at $6 \mathrm{~h}$ ), the fast lipid accumulation stage (at $24 \mathrm{~h}$ ) and the stable stage of lipid accumulation (at $60 \mathrm{~h}$ ) were filtered as above and washed with cold distilled water at $4{ }^{\circ} \mathrm{C}$. The collected mycelia were flash-frozen in liquid $\mathrm{N}_{2}$ and stored at $-80{ }^{\circ} \mathrm{C}$. For each condition, protein extraction was performed according to a modified version of the method of Liu et al. [51] and Chen et al. [52]. The frozen mycelia were ground in liquid $\mathrm{N}_{2}$, resuspended in cold $10 \%(\mathrm{w} / \mathrm{v})$ trichloracetic acid/acetone and allowed to precipitate at $-20{ }^{\circ} \mathrm{C}$ for $1 \mathrm{~h}$. The samples were centrifuged at $15,000 \mathrm{~g}$ for $15 \mathrm{~min}$ at $4{ }^{\circ} \mathrm{C}$ and the supernatant was discarded. The pellets were resuspended in cold acetone, kept at $-20{ }^{\circ} \mathrm{C}$ for $1 \mathrm{~h}$ and then centrifuged at $15,000 \mathrm{~g}$ for $15 \mathrm{~min}$ at $4{ }^{\circ} \mathrm{C}$. This procedure was repeated twice. The pellets were freeze-dried, suspended in approx. $10 \mathrm{~mL}$ extraction buffer [0.7 M sucrose, $0.1 \mathrm{M}$ $\mathrm{NaCl}, 0.5 \mathrm{M}$ Tris/ $\mathrm{HCl}$ (pH 7.5), $50 \mathrm{mM}$ EDTA and $0.2 \%$ DTT], mixed with an equal volume of Tris/saturated phenol $(1 \mathrm{~g} / 100 \mathrm{~mL})(\mathrm{pH} 7.5)$ and then homogenized for $30 \mathrm{~min}$ at $4{ }^{\circ} \mathrm{C}$. The homogenate was centrifuged at $5000 \mathrm{~g}$ for $10 \mathrm{~min}$ at $4{ }^{\circ} \mathrm{C}$ to collect the phenol phase and the phenol extraction was repeated three time. The combined phenol phases were mixed with five volumes of a precipitation buffer $(0.1 \mathrm{M}$ ammonium acetate in methanol). Precipitation was carried out at $-20{ }^{\circ} \mathrm{C}$ for $1 \mathrm{~h}$ and the pellets were washed three times with cold methanol followed by rinsing three time with cold acetone. The protein pellets were dissolved in a lysis buffer [ $9 \mathrm{M}$ urea, $4 \%$ CHAPS, $1 \%$ immobilized $\mathrm{pH}$ gradient buffer $(\mathrm{pH}$ 3-10) and $1 \%$ DTT] and then centrifuged at 15,000g for $15 \mathrm{~min}$. The supernatants were collected and protein concentrations were determined according to the Bradford method with BSA as a standard.

\section{2-DE}

Before 2-DE, $1200 \mu \mathrm{g}$ protein solution was mixed with rehydration buffer [9 M urea, $4 \%$ CHAPS, $1 \%$ immobilized $\mathrm{pH}$ gradient buffer (pH 3-10), 1 \% DTT and $0.002 \%$ Bromphenol Blue] and then loaded onto the IPG strip $(\mathrm{pH} \mathrm{3-10,} \mathrm{nonlinear,} \mathrm{24} \mathrm{cm).} \mathrm{Strips} \mathrm{were} \mathrm{focused} \mathrm{on} \mathrm{a}$ IPGhor Isoelectric Focusing System (GE Healthcare) 
at $20{ }^{\circ} \mathrm{C}$ with the following program: $50 \mathrm{~V}$ for $12 \mathrm{~h}$ (for rehydration), $100 \mathrm{~V}$ for $1 \mathrm{~h}, 200 \mathrm{~V}$ for $1 \mathrm{~h}, 500 \mathrm{~V}$ for $1 \mathrm{~h}$, $1000 \mathrm{~V}$ for $1 \mathrm{~h}$, gradient from 1000 to $10,000 \mathrm{~V}$ within $1 \mathrm{~h}$ and $10,000 \mathrm{~V}$ for $11 \mathrm{~h}$. After that, strips were equilibrated at room temperature in two steps: $15 \mathrm{~min}$ in equilibration buffer $[50 \mathrm{mM}$ Tris/ $\mathrm{HCl}(\mathrm{pH} 8.8), 6 \mathrm{M}$ urea, $30 \%$ $\mathrm{w} / \mathrm{v}$ glycerol and $2 \% \mathrm{w} / \mathrm{v}$ SDS] with the addition of $1 \%$ DTT followed by $15 \mathrm{~min}$ in equilibration buffer with the addition of $2.5 \%(\mathrm{w} / \mathrm{v})$ iodoacetamide. The equilibrated strips were transferred onto $12 \%$ SDS-PAGE for the second dimension electrophoresis by using DALT-SIX SDSPAGE Vertical System (GE Healthcare) at $15^{\circ} \mathrm{C}$ with two steps: $100 \mathrm{~V}$ for $45 \mathrm{~min}$ and $200 \mathrm{~V}$ until the Bromophenol Blue reached the bottom of the gel. The gels were fixed with $10 \%(\mathrm{w} / \mathrm{v})$ trichloroacetic acid and stained with Coomassie Brilliant Blue G-250.

\section{Image analysis}

Nine 2-DE gels (three independent analytical replicate gels for each growth stage) were scanned at $300 \mathrm{dpi}$ using Image Scanner LabScan (GE Healthcare). Spot detection, gel matching and group analysis of the gels were performed using PDQuest 8.0 software (Bio-Rad). Quantitative analyses were carried out after normalizing the quantities of spots in all gels in order to compensate for non-expression related variations, and quantity of each spot was normalized by total valid spot intensity. For each spot, the mean quantity was computed at every stage, and the spots showing a mean value that changed more than 1.5 -fold or less than 0.67 -fold $(\mathrm{P}<0.05)$ in different stages were considered differentially expressed proteins.

\section{Protein identification and database search}

Protein spots with different expression levels were manually excised from the gels, washed with Millipore pure water for three times, destained three times with $100 \mathrm{mM} \mathrm{NH}_{4} \mathrm{HCO}_{3}$ in $30 \%(\mathrm{v} / \mathrm{v})$ acetonitrile, and then vacuum dried. Every protein spot was digested overnight with $50 \mathrm{ng}$ trypsin (Promega) in $30 \mu \mathrm{l} 25 \mathrm{mM} \mathrm{NH}_{4} \mathrm{HCO}_{3}$ containing $10 \%(\mathrm{v} / \mathrm{v})$ acetonitrile at $37{ }^{\circ} \mathrm{C}$. The supernatants were transferred into another tube followed by vacuum dried. The dried peptides were dissolved in $0.1 \%$ trifluoroacetic acid and mixed with an equal volume of $0.7 \mathrm{mg} \alpha$-cyano-4-hydroxy-trans-cinnamic acid/ $\mathrm{mL}$ in acetonitrile/trifluoroacetic acid (85:0.1 v/v), and then spotted on the sample target plate for analysis using UltrafleXtrem MALDI-TOF/TOF mass spectrometer (Bruker-Daltonics). Tryptic peptides were analyzed in the positive ion reflector mode, and spectra were calibrated using Bruker peptide calibration standard II (BrukerDaltonics). At least 10 peptide fragments were selected to be analyzed in lift mode. Then spectra were processed by FlexAnalysis software and analyzed by BioTools software
(Bruker-Daltonics). An in-house Mascot server (http:// www.matrixscience.com) was used for database search and the following parameters were used in the search: NCBInr fungi database; trypsin as the digestion enzyme; monoisotopic peptide values; a maximum of one missed cleavage per peptide; fragment mass tolerance of $0.99 \mathrm{Da}$ and peptide mass tolerance of $300 \mathrm{ppm}$, together with the acceptance of cysteine carbamidomethylation (fixed modifications) and methionine oxidation (variable modifications). For a positive identification, a score calculated by the Mowse scoring algorithm in MASCOT was considered as significant $(\mathrm{P}<0.05)$.

\section{Quantitative RT-PCR}

Quantitative RT-PCR analysis was performed to quantify the transcriptional levels of genes. Total RNA was extracted from samples taken at the three growth stages with TRIzol and then converted to cDNA using a PrimeScrip 1st strand cDNA Synthesis Kit (Takara) according to the manufacturer's instructions. The quantitative RTPCR reaction was performed with CFX Connect RealTime System (Bio-Rad) and iTaq Universal SYBR Green PCR Supermix (Bio-Rad) was used to identify mRNA level. The primer pairs are listed in Additional file 2: Table S2 using the 18S rRNA of M. circinelloides WJ11 as an internal control in PCR amplification.

\section{Statistical analysis}

The mean values and the standard error of the mean were calculated from the data obtained from three biological replicates. A statistical analysis of the obtained data was carried out using SPSS 16.0 for Windows (SPSS Inc., Chicago, IL). One way analysis of variance (ANOVA) with Tukey's test was conducted on the data, and $\mathrm{P}<0.05$ was considered significantly different.

\section{Additional files}

Additional file 1: Table S1. Fatty acid composition and GLA production in M. circinelloides WJ11 at $6 \mathrm{~h}, 24 \mathrm{~h}$ and $60 \mathrm{~h}$.

Additional file 2: Table S2. Primer sequences used for qRT-PCR.

\section{Abbreviations}

N: nitrogen; CDW: cell dry weight; PUFAs: polyunsaturated fatty acids; GLA: $\gamma$-linolenic acid; ACL, ATP: citrate lyase; TFAs: total fatty acids; GS: glutamine synthase; BCAA: branched-chain amino acids; SAS: S-adenosylmethionine synthase; ROS: reactive oxygen species; FBA: fructose-bisphosphate aldolase; G3P: glyceraldehyde 3-phosphate; DHAP: dihydroxyacetone phosphate; PDH: pyruvate dehydrogenase; PGM: phosphoglycerate mutase; 3PGA: 3-phosphoglycerate; 2PGA: 2-phosphoglycerate; PPP: pentose phosphate pathway; ME: malic enzyme; G6PDH: glucose-6-phosphate dehydrogenase; NAD ${ }^{+}: I C D H$ : $\mathrm{NAD}^{+}$:isocitrate dehydrogenase; ALDH: aldehyde dehydrogenase; ACS: acetylCoA synthase; ACAT: acetyl-CoA C-acetyltransferase; TBE: thiazole biosynthetic enzyme; HSPs: heat shock proteins; Prx: peroxiredoxin; GPx: glutathione peroxidase. 


\section{Authors' contributions}

XT carried out the experiments and drafted the manuscript. XZ and LZ participated in protein identification and database search. HC, YQC, WC, YS, and CR participated in the experimental design and reviewed the manuscript. YS and CR conceived the study and reviewed the final manuscript. All authors read and approved the final manuscript.

\section{Author details}

${ }^{1}$ State Key Laboratory of Food Science and Technology, School of Food Science and Technology, Jiangnan University, Wuxi, People's Republic of China. ${ }^{2}$ Colin Ratledge Center for Microbial Lipids, School of Agriculture Engineering and Food Science, Shandong University of Technology, Zibo, People's Republic of China. ${ }^{3}$ Synergistic Innovation Center for Food Safety and Nutrition, Wuxi, People's Republic of China. ${ }^{4}$ Department of Biological Sciences, University of Hull, Hull, UK.

\section{Acknowledgements}

This work was supported by the National Natural Science Foundation of China (31271812, 31530056, 21276108), the National High Technology Research and Development Program of China (2012AA022105C), the Program for Changjiang Scholars and Innovative Research Team in University (IRT1249), the Program for New Century Excellent Talents (NCET-13-0831), and the Strategic Merieux Research Grant.

\section{Competing interests}

The authors declare that they have no competing interests.

Received: 16 October 2015 Accepted: 19 January 2016 Published online: 11 February 2016

\section{References}

1. Thorpe R, Ratledge C. Fatty acid distribution in triglycerides of yeasts grown on glucose or n-alkanes. J Gen Microbiol. 1972;72:151-63.

2. Ratledge $C$. The role of malic enzyme as the provider of NADPH in oleaginous microorganisms: a reappraisal and unsolved problems. Biotech Lett. 2014;36:1557-68.

3. Ratledge C, Wynn JP. The biochemistry and molecular biology of lipid accumulation in oleaginous microorganisms. Adv Appl Microbiol. 2002;51:1-51.

4. Ratledge C. Microbial production of gamma-linolenic acid. In: Akoh CC, editor. Handbook of functional lipids. Boca Raton: CRC Press; 2005. p. 19-45.

5. Botham PA, Ratledge C. A biochemical explanation for lipid accumulation in Candida 107 and other oleaginous micro-organisms. J Gen Microbiol. 1979;114:361-75.

6. Tang X, Chen H, Chen YQ, Chen W, Garre V, Song Y, Ratledge C. Comparison of biochemical activities between high and low lipid-producing strains of Mucor circinelloides: an explanation for the high oleaginicity of strain WJ11. PLoS ONE. 2015;10:e0128396.

7. Boulton CA, Ratledge C. Correlation of lipid accumulation in yeasts with possession of ATP: citrate lyase. J Gen Microbiol. 1981;127:169-76.

8. Tamano K, Bruno KS, Karagiosis SA, Culley DE, Deng S, Collett JR, Umemura M, Koike H, Baker SE, Machida M. Increased production of fatty acids and triglycerides in Aspergillus oryzae by enhancing expressions of fatty acid synthesis-related genes. Appl Microbiol Biotechnol. 2013;97:269-81.

9. Zhang H, Zhang L, Chen H, Chen YQ, Chen W, Song Y, Ratledge C. Enhanced lipid accumulation in the yeast Yarrowia lipolytica by overexpression of ATP: citrate lyase from Mus musculus. J Biotechnol. 2014;192:78-84

10. Wynn JP, bin Abdul Hamid A, Ratledge C. The role of malic enzyme in the regulation of lipid accumulation in filamentous fungi. Microbiology. 1999;145:1911-7

11. Wynn JP, Ratledge C. Malic enzyme is a major source of NADPH for lipid accumulation by Aspergillus nidulans. Microbiology. 1997;143:253-7.

12. Zhu Z, Zhang S, Liu H, Shen H, Lin X, Yang F, Zhou YJ, Jin G, Ye M, Zou H. A multi-omic map of the lipid-producing yeast Rhodosporidium toruloides. Nat Commun. 2012;3:1112.
13. Liu Z, Gao Y, Chen J, Imanaka T, Bao J, Hua Q. Analysis of metabolic fluxes for better understanding of mechanisms related to lipid accumulation in oleaginous yeast Trichosporon cutaneum. Bioresour Technol. 2013;130:144-51.

14. Paula Alonso A, Dale VL, Shachar Hill Y. Understanding fatty acid synthesis in developing maize embryos using metabolic flux analysis. Metab Eng. 2010;12:488-97.

15. Xiong W, Liu L, Wu C, Yang C, Wu Q. 13C-tracer and gas chromatography-mass spectrometry analyses reveal metabolic flux distribution in the oleaginous microalga Chlorella protothecoides. Plant Physiol. 2010;154:1001-11.

16. Wasylenko TM, Ahn WS, Stephanopoulos G. The oxidative pentose phosphate pathway is the primary source of NADPH for lipid overproduction from glucose in Yarrowia lipolytica. Metab Eng. 2015;30:27-39.

17. Zhao L, Zhang H, Wang L, Chen H, Chen YQ, Chen W, Song Y. 13 C-metabolic flux analysis of lipid accumulation in the oleaginous fungus Mucor circinelloides. Bioresour Technol. 2015;197:23-9.

18. Yang ZK, Ma YH, Zheng JW, Yang WD, Liu JS, Li HY. Proteomics to reveal metabolic network shifts towards lipid accumulation following nitrogen deprivation in the diatom Phaeodactylum tricornutum. J Appl Phycol. 2014;26:73-82.

19. Garnier M, Carrier G, Rogniaux H, Nicolau E, Bougaran G, Saint-Jean B, Cadoret J-P. Comparative proteomics reveals proteins impacted by nitrogen deprivation in wild-type and high lipid-accumulating mutant strains of Tisochrysis lutea. J Proteomics. 2014;105:107-20.

20. Song P, Li L, Liu J. Proteomic analysis in nitrogen-deprived/sochrysis galbana during lipid accumulation. PLOS ONE. 2013;8:e82188.

21. Liu H, Zhao X, Wang F, Li Y, Jiang X, Ye M, Zhao ZK, Zou H. Comparative proteomic analysis of Rhodosporidium toruloides during lipid accumulation. Yeast. 2009;26:553-66.

22. Chen H, Hao G, Wang L, Wang H, Gu Z, Liu L, Zhang H, Chen W, Chen YQ Identification of a critical determinant that enables efficient fatty acid synthesis in oleaginous fungi. Sci Rep. 2015:5:11247.

23. Xia C, Zhang J, Zhang W, Hu B. A new cultivation method for microbial oil production: cell pelletization and lipid accumulation by Mucor circinelloides. Biotechnol Biofuels. 2011;4:1-10.

24. Tang $X$, Zhang $H$, Chen $H$, Chen $Y Q$, Chen W, Song Y. Effects of 20 standard amino acids on the growth, total fatty acids production, and $\gamma$-linolenic acid yield in Mucor circinelloides. Curr Microbiol. 2014;69:899-908.

25. Stacey G, Van Baalen C, Tabita FR. Nitrogen and ammonia assimilation in the cyanobacteria: regulation of glutamine synthetase. Arch Biochem Biophys. 1979;194:457-67.

26. Magasanik B, Kaiser CA. Nitrogen regulation in Saccharomyces cerevisiae. Gene. 2002;290:1-18.

27. Chipman D, Ze Barak, Schloss JV. Biosynthesis of 2-aceto-2-hydroxy acids: acetolactate synthases and acetohydroxyacid synthases. BBA Protein Struct Mol Enzymol. 1998;1385:401-19.

28. Myers JW. Dihydroxy acid dehydrase: an enzyme involved in the biosynthesis of isoleucine and valine. J Biol Chem. 1961;236:1414-8.

29. Chunduru SK, Mrachko GT, Calvo K. Mechanism of ketol acid reductoisomerase. Steady-state analysis and metal ion requirement. Biochemistry. 1989;28:486-93.

30. Ichihara A, Koyama E. Transaminase of branched chain amino acids. J Biochem. 1966;59:160-9.

31. Huber TA, Streeter JG. Asparagine biosynthesis in soybean nodules. Plant Physiol. 1984;74:605-10.

32. Fujioka M, Nakatani Y. Saccharopine dehydrogenase. Eur J Biochem. 1972;25:301-7.

33. Miyazaki J, Kobashi N, Nishiyama M, Yamane H. Characterization of homoisocitrate dehydrogenase involved in lysine biosynthesis of an extremely thermophilic bacterium, Thermus thermophilus HB27, and evolutionary implication of $\beta$-decarboxylating dehydrogenase. J Biol Chem. 2003;278:1864-71.

34. Kikuchi $\mathrm{G}$. The glycine cleavage system: composition, reaction mechanism, and physiological significance. Mol Cell Biochem. 1973;1:169-87.

35. Lu SC. S-adenosylmethionine. Int J Biochem cell B. 2000;32:391-5.

36. Shin R, Berg RH, Schachtman DP. Reactive oxygen species and root hairs in Arabidopsis root response to nitrogen, phosphorus and potassium deficiency. Plant Cell Physiol. 2005;46:1350-7.

37. Guy C, Carter J. Effect of low temperature on the glutathione status of plant cells. Plant Cold Hardiness Freez Stress. 1982;2:169-79. 
38. Kendrick A, Ratledge C. Desaturation of polyunsaturated fatty acids in Mucor circinelloides and the involvement of a novel membrane-bound malic enzyme. Eur J Biochem. 1992;209:667-73.

39. Marsh JJ, Lebherz HG. Fructose-bisphosphate aldolases: an evolutionary history. Trends Biochem Sci. 1992;17:110-3.

40. Song Y, Wynn JP, Li Y, Grantham D, Ratledge C. A pre-genetic study of the isoforms of malic enzyme associated with lipid accumulation in Mucor circinelloides. Microbiology. 2001;147:1507-15.

41. Zhang Y, Adams IP, Ratledge C. Malic enzyme: the controlling activity for lipid production? Overexpression of malic enzyme in Mucor circinelloides leads to a 2.5-fold increase in lipid accumulation. Microbiology. 2007;153:2013-25.

42. Noctor G, Mhamdi A, Chaouch S, Han Y, Neukermans J, Marquez-Garcia B, Queval G, Foyer CH. Glutathione in plants: an integrated overview. Plant, Cell Environ. 2012;35:454-84.

43. Machado C, Oliveira RCL, Boiteux S, Praekelt UM, Meacock PA, Menck CFM. Thi1, a thiamine biosynthetic gene in Arabidopsis thaliana, complements bacterial defects in DNA repair. Plant Mol Biol. 1996;31:585-93.

44. Machado CR, Praekelt UM, Oliveira RCL, Barbosa ACC, Byrne KL, Meacock PA, Menck CF. Dual role for the yeast THI4 gene in thiamine biosynthesis and DNA damage tolerance. J Mol Biol. 1997;273:114-21.

45. Wynn JP, Hamid AA, Li Y, Ratledge C. Biochemical events leading to the diversion of carbon into storage lipids in the oleaginous fungi Mucor circinelloides and Mortierella alpina. Microbiology. 2001;147:2857-64.
46. Hermeking $H$, Benzinger A. 14-3-3 proteins in cell cycle regulation. Semin Cancer Biol. 2006;16:183-92.

47. Choi YE, Kwon KW, Lee JC, Woo SY. Expression of the rice cytoplasmic cysteine synthase gene in tobacco reduces ozone-induced damage. Plant Biotechnol Rep. 2007;1:93-100.

48. Bell A, Monaghan P, Page AP. Peptidyl-prolyl cis-trans isomerases (immunophilins) and their roles in parasite biochemistry, host-parasite interaction and antiparasitic drug action. Int J Parasitol. 2006;36:261-76.

49. Tang X, Zhao L, Chen H, Chen YQ, Chen W, Song Y, Ratledge C. Complete genome sequence of a high lipid-producing strain of Mucor circinelloides WJ11 and comparative genome analysis with a low lipid-producing strain CBS 277.49. PLoS ONE. 2015;10:e0137543.

50. Chaney AL, Marbach EP. Modified reagents for determination of urea and ammonia. Clin Chem. 1962;8:130-2.

51. Liu X, Wu H, Ji C, Wei L, Zhao J, Yu J. An integrated proteomic and metabolomic study on the chronic effects of mercury in Suaeda salsa under an environmentally relevant salinity. PLOS ONE. 2013;8:e64041.

52. Chen Y, Pang Q, Dai S, Wang Y, Chen S, Yan X. Proteomic identification of differentially expressed proteins in Arabidopsis in response to methyl jasmonate. J Plant Physiol. 2011;168:995-1008.

\section{Submit your next manuscript to BioMed Central and we will help you at every step:}

- We accept pre-submission inquiries

- Our selector tool helps you to find the most relevant journal

- We provide round the clock customer support

- Convenient online submission

- Thorough peer review

- Inclusion in PubMed and all major indexing services

- Maximum visibility for your research

Submit your manuscript at www.biomedcentral.com/submit

() Biomed Central 